\title{
Photo-click facilitated screening platform for the development of hetero-bivalent agents with high potency
}

Lingyi Sun, ${ }^{\mathrm{a}, \mathrm{b}, \dagger}$ Yongkang Gai, ${ }^{\mathrm{a}, \dagger}$ Christopher D. McNitt, ${ }^{\mathrm{c}}$ Jun Sun, ${ }^{\mathrm{a}, \mathrm{d}}$ Xiaohui Zhang, ${ }^{\mathrm{a}}$ Wei Xing, ${ }^{d}$ Zhonghan Li ${ }^{\mathrm{b}}$, Vladimir V. Popik, ${ }^{\mathrm{c}}$ and Dexing Zeng ${ }^{\mathrm{a}, \mathrm{b}, *}$

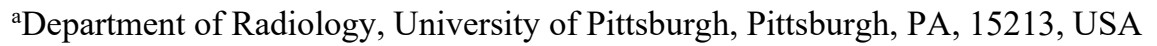

bDepartment of Diagnostic Radiology, Oregon Health \& Science University, Portland, OR, 97229, USA ${ }^{\mathrm{c}}$ Department of Chemistry, University of Georgia, Athens, GA, 30602, USA

dDepartment of Radiology, Third Affiliated Hospital of Suzhou University, Changzhou, Jiangsu, 213003, China 
Table of Content

\begin{tabular}{clc}
\hline Item & \multicolumn{1}{c}{ Content } & Page \\
\hline 1 & Photo triggered click chemistry based on photo-ODIBO & $\mathrm{S3}$ \\
2 & Saturation binding assay & $\mathrm{S3}$ \\
3 & $\begin{array}{l}\text { Estimation of the distance between one integrin ovß3 receptor } \\
\text { and one uPAR on U87MG cell surface }\end{array}$ & $\mathrm{S} 4$ \\
4 & Preparation of RGD-PEG4-photo-ODIBO and AE105-PEGn-N & $\mathrm{S} 4$ \\
5 & HPLC condition for monitoring the RGD modification & $\mathrm{S} 4$ \\
6 & HPLC analysis of the AE105-PEG4-N3 preparation & $\mathrm{S5}$ \\
7 & Purity of isolated chemical tools & $\mathrm{S6}$ \\
8 & Absorption spectrum of RGD-PEG4-photo-ODIBO and the & $\mathrm{S8}$ \\
& activated product RGD-PEG4-ODIBO & $\mathrm{S9}$ \\
9 & Preparation of heterodimers with different linkers & $\mathrm{S9}$ \\
10 & Statistical analysis & \\
\hline
\end{tabular}




\section{Photo triggered click chemistry based on photo-ODIBO}

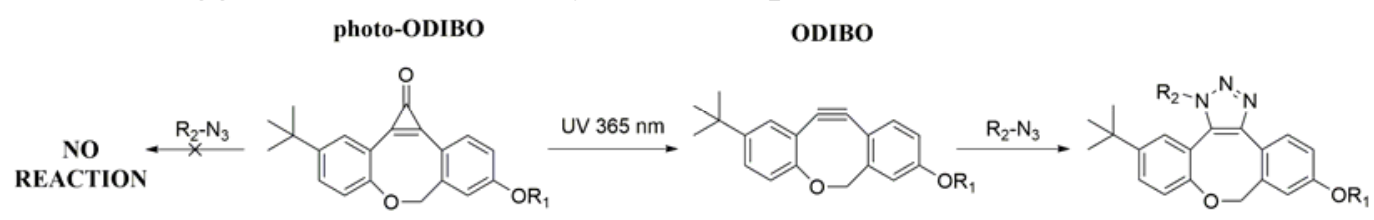

Scheme S1. Photo triggered click chemistry based on photo-ODIBO.

\section{Saturation binding assay}

Cells were seeded in 24-well plates (100,000 cells per well) $24 \mathrm{~h}$ before the experiment. Before the experiment, cells were washed with $1 \mathrm{~mL}$ HBSS twice and $0.5 \mathrm{~mL}$ binding media (HBSS with $0.1 \% \mathrm{BSA}$ and $1 \mathrm{mM} \mathrm{Mn}^{2+}$ ) was added to each well. Then blocking agent (10 $\mu$ g AE105 for $\left({ }^{64} \mathrm{Cu}\right) \mathrm{AE} 105,10 \mu \mathrm{g}$ RGD for $\left.\left({ }^{64} \mathrm{Cu}\right) \mathrm{RGD}\right)$ was added to half of the wells as cold block to determine in vitro non-specific binding, followed by $\left({ }^{64} \mathrm{Cu}\right) \mathrm{AE} 105$ or $\left({ }^{64} \mathrm{Cu}\right) \mathrm{RGD}$ in increased concentrations. Samples were incubated for 2 $\mathrm{h}$ on ice $\left(4{ }^{\circ} \mathrm{C}\right)$. After incubation, the radioactive media was removed. Cell pellets were rinsed with ice cold binding buffer $(1 \mathrm{~mL})$ twice and dissolved in $0.5 \%$ SDS solution. The radioactivity in each cell lysate sample was measured in a gamma counter. The protein content of each cell lysate sample was determined by Pierce BCA Protein Assay Kit. The measured radioactivity associated with each cell lysate sample was normalized to the amount of cell protein present ( $\mathrm{fmol} / \mathrm{mg}$ ).

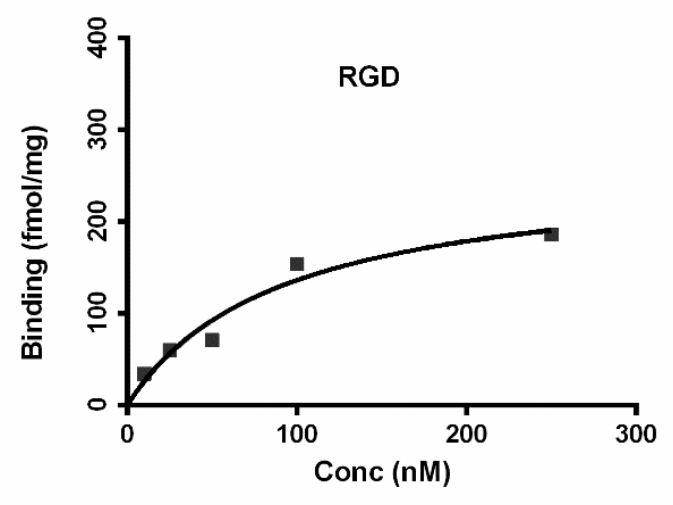

(a)

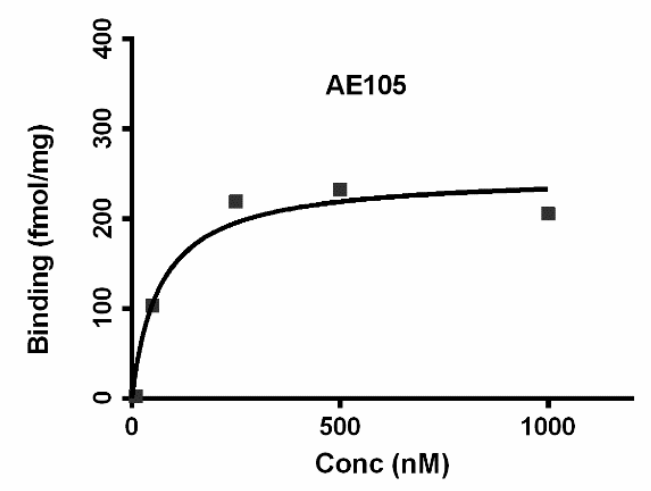

(b)

Figure S1. Saturation binding assay of RGD (a) and AE105 (b) for quantifying integrin $\alpha v \beta 3$ and $\mathrm{uPAR}$, respectively. 


\section{Estimation of the distance between one integrin $\alpha v \beta 3$ receptor and one $u P A R$ on U87MG cell surface}

Bmax values for RGD and AE105 on U87MG cells were found to be at the scale of hundreds of fmole/mg (Figure S1), thus the amounts of receptors corresponding to $1 \mathrm{mg}$ protein should be at the scale of $10^{\wedge} 11$. Based on the protein quantification, the number of U87MG cells containing $1 \mathrm{mg}$ protein was at the scale of $10^{\wedge} 5$. Therefore, the numbers of receptors on each cell would be at the scale of $10^{\wedge} 6$ (the number of receptors/the number of cells). Considering the radius of the cell was around $5 \mu \mathrm{m}$, the density of the receptor on the cell surface could be at the scale of 1 receptor per $100 \mathrm{~nm}^{2}$. Therefore, on average there could be around one pair of integrin $\alpha v \beta 3$ receptor and uPAR distributed within $100 \mathrm{~nm}^{2}$ surface area theoretically, indicating the possible distance between two receptors might be $6 \mathrm{~nm}(60 \AA \hat{)})$ or less (Consider setting one receptor as the center and drawing a circle that covers $100 \mathrm{~nm}^{2}$ area, then the radius of this circle would be less than $6 \mathrm{~nm})$.

\section{Preparation of RGD -PEG4- photo-ODIBO and AE105-PEGn-N 3}

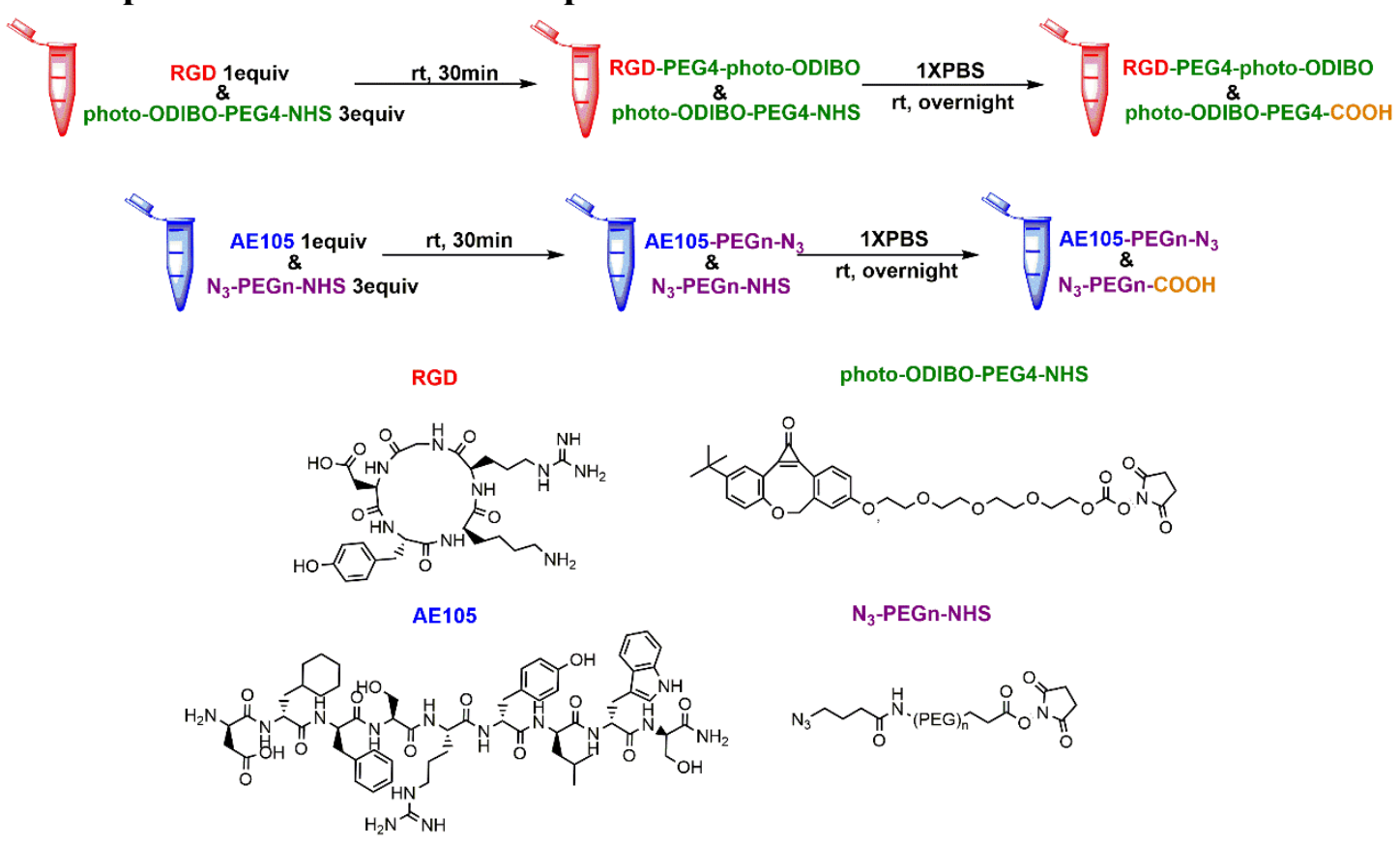

Scheme S2. Preparation of photo-ODIBO-PEG4-RGD and AE105-PEGn-N 3.

\section{HPLC condition for monitoring the RGD modification}

0-2 min, $100 \% \mathrm{H}_{2} \mathrm{O} ; 2-12 \mathrm{~min}$, changing from $100 \% \mathrm{H}_{2} \mathrm{O}$ to $80 \% \mathrm{H}_{2} \mathrm{O} \& 20 \% \mathrm{ACN}$; $12-22$ min, changing from $80 \% \mathrm{H}_{2} \mathrm{O} \& 20 \% \mathrm{ACN}$ to $10 \% \mathrm{H}_{2} \mathrm{O} \& 90 \% \mathrm{ACN} ; 22-26$ min, $10 \% \mathrm{H}_{2} \mathrm{O} \& 90 \% \mathrm{ACN}$; $26-27$ min changing from $10 \% \mathrm{H}_{2} \mathrm{O} \& 90 \% \mathrm{ACN}$ to $100 \%$ $\mathrm{H}_{2} \mathrm{O} ; 27-35 \mathrm{~min}, 100 \% \mathrm{H}_{2} \mathrm{O}$. Flow rate $=1.5 \mathrm{~mL} / \mathrm{min}, \mathrm{UV}=254 \mathrm{~nm}$. 


\section{HPLC analysis of the AE105-PEG4-N 3 preparation}

HPLC conditions: $0-2 \mathrm{~min}, 100 \% \mathrm{H}_{2} \mathrm{O} ; 2-22 \mathrm{~min}$, changing from $100 \% \mathrm{H}_{2} \mathrm{O}$ to $40 \% \mathrm{H}_{2} \mathrm{O} \& 60 \% \mathrm{ACN} ; 22-23 \mathrm{~min}$, changing from $40 \% \mathrm{H}_{2} \mathrm{O} \& 60 \% \mathrm{ACN}$ to $10 \%$ $\mathrm{H}_{2} \mathrm{O} \& 90 \% \mathrm{ACN} ; 23-27 \mathrm{~min}, 10 \% \mathrm{H}_{2} \mathrm{O} \& 90 \% \mathrm{ACN} ; 27-28$ min changing from $10 \% \mathrm{H}_{2} \mathrm{O} \& 90 \% \mathrm{ACN}$ to $100 \% \mathrm{H}_{2} \mathrm{O} ; 28-33 \mathrm{~min}, 100 \% \mathrm{H}_{2} \mathrm{O}$. Flow rate $=$ $1.5 \mathrm{~mL} / \mathrm{min}, \mathrm{UV}=210 \mathrm{~nm}$.

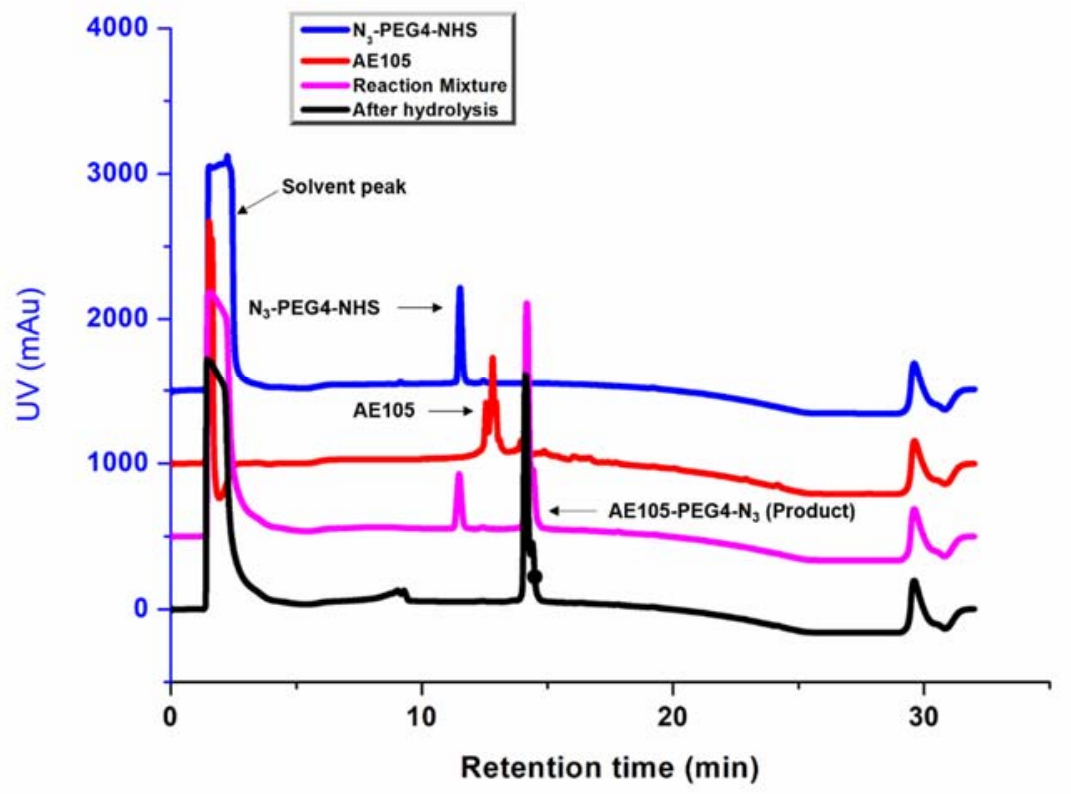

Figure S2. HPLC graphs of AE105-PEG4-N 3 preparation monitored at 210nm. The AE105 peak at $12 \mathrm{~min}$ (red trace) almost disappeared in the spectrum of the reaction mixture (pink trace) after a 30min incubation while the product peak appeared at the retention time of $14 \mathrm{~min}$, indicating a highly efficient conversion from AE105 to AE105-PEG4-N ${ }_{3}$. In addition, a complete hydrolysis of $\mathrm{N}_{3}$-PEG4-NHS (peak at $11 \mathrm{~min}$, blue race) was observed after the hydrolysis step. Since $\mathrm{N}_{3}$-PEG4-NHS does not contain any big conjugating system such as an aromatic ring, it has to be monitored at UV210nm, which leads to an obvious solvent peak. 


\section{Purity of isolated chemical tools}

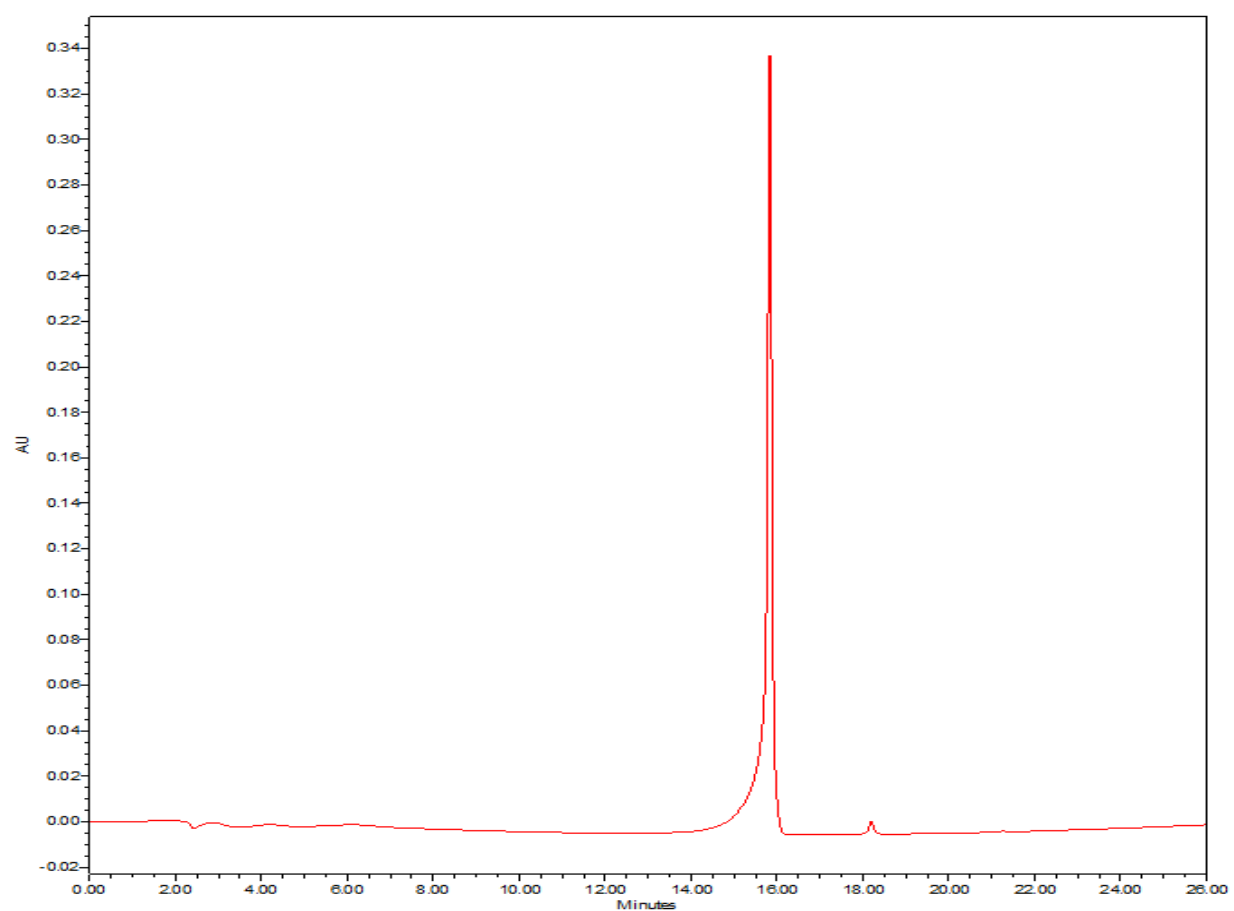

Figure S3. Purity analysis of isolated photo-RGD-PEG4-photo-ODIBO.

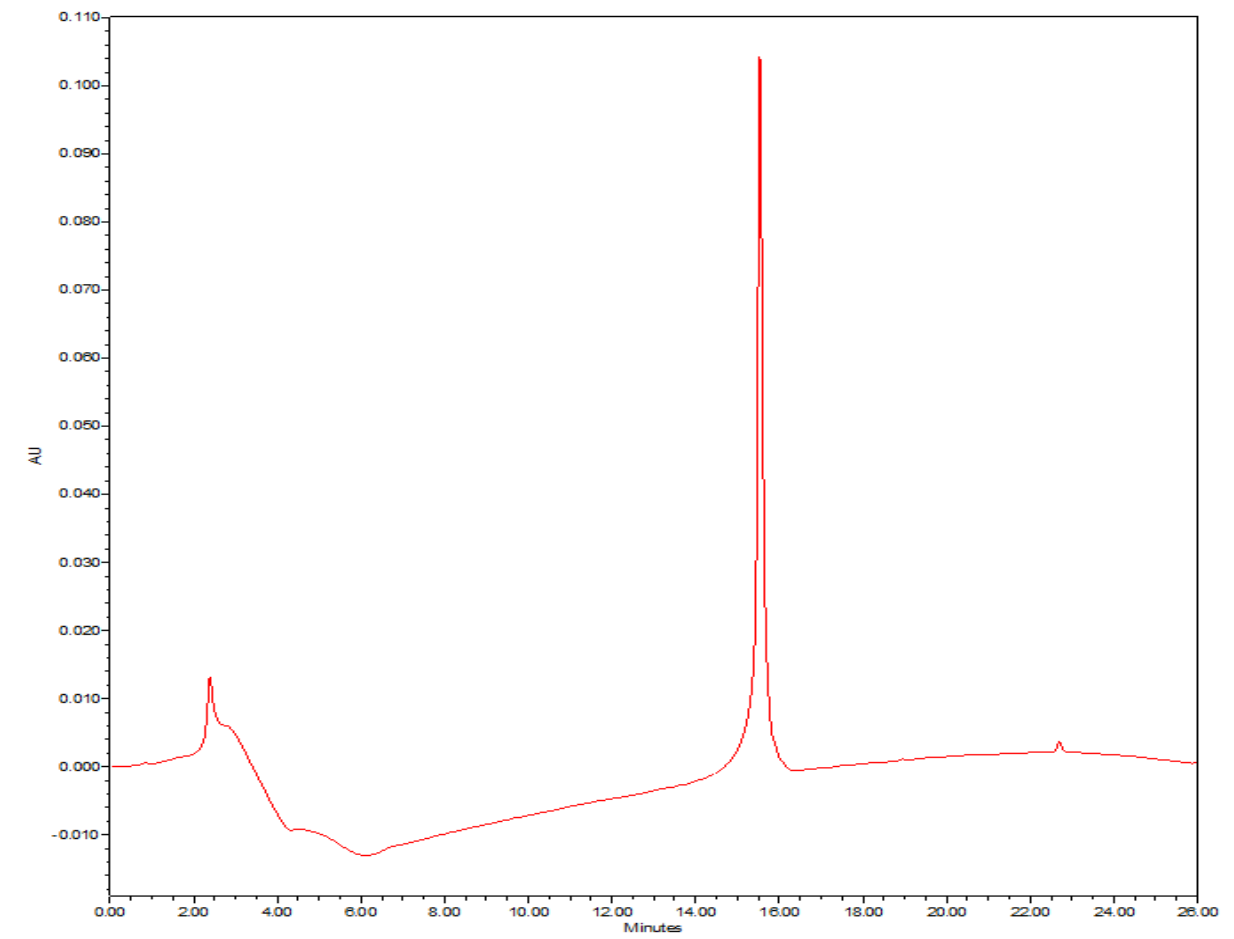

Figure S4. Purity analysis of isolated AE105-N3 via analytic HPLC. 


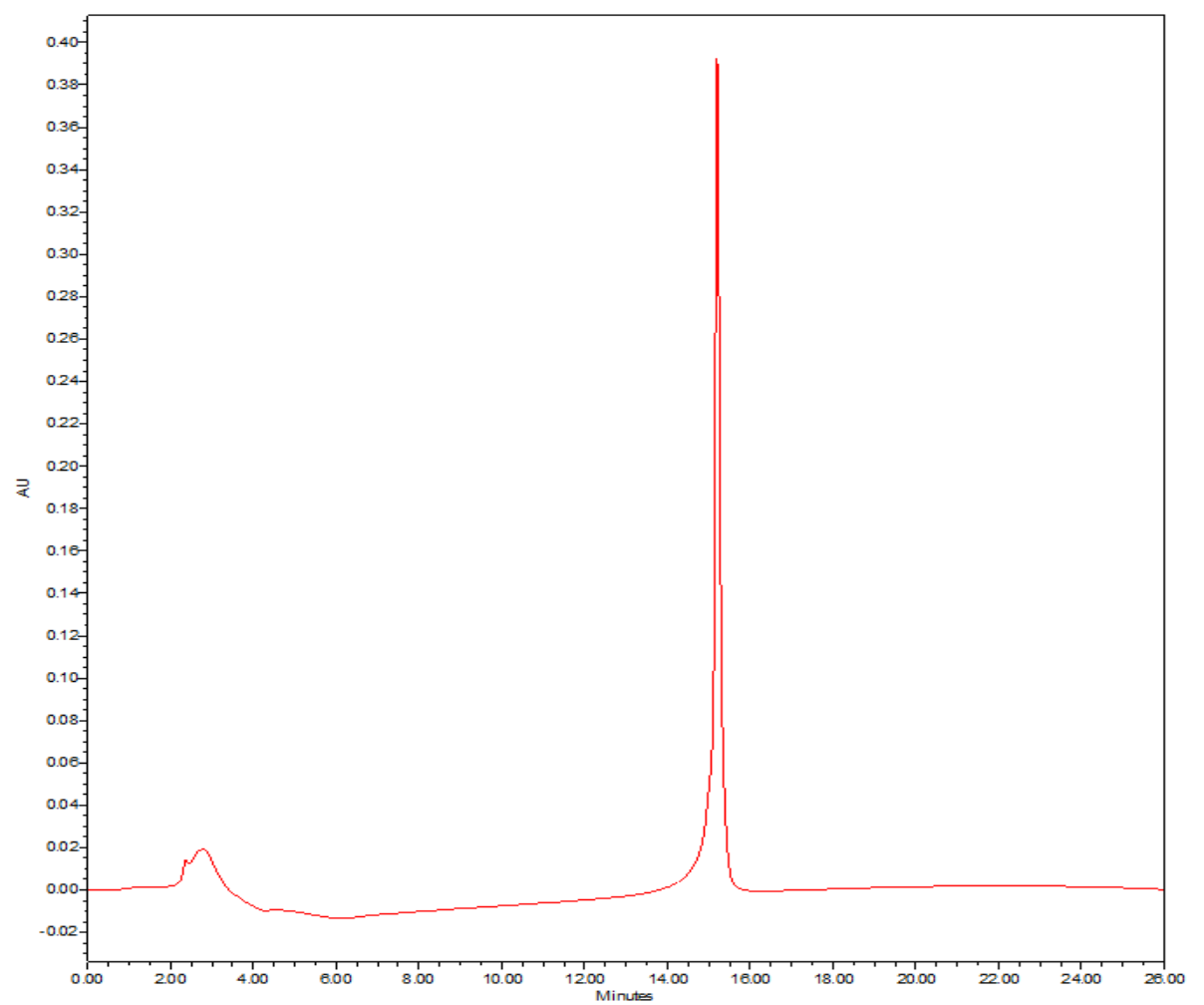

Figure S5. Purity analysis of isolated AE105-PEG4-N3 via analytic HPLC.

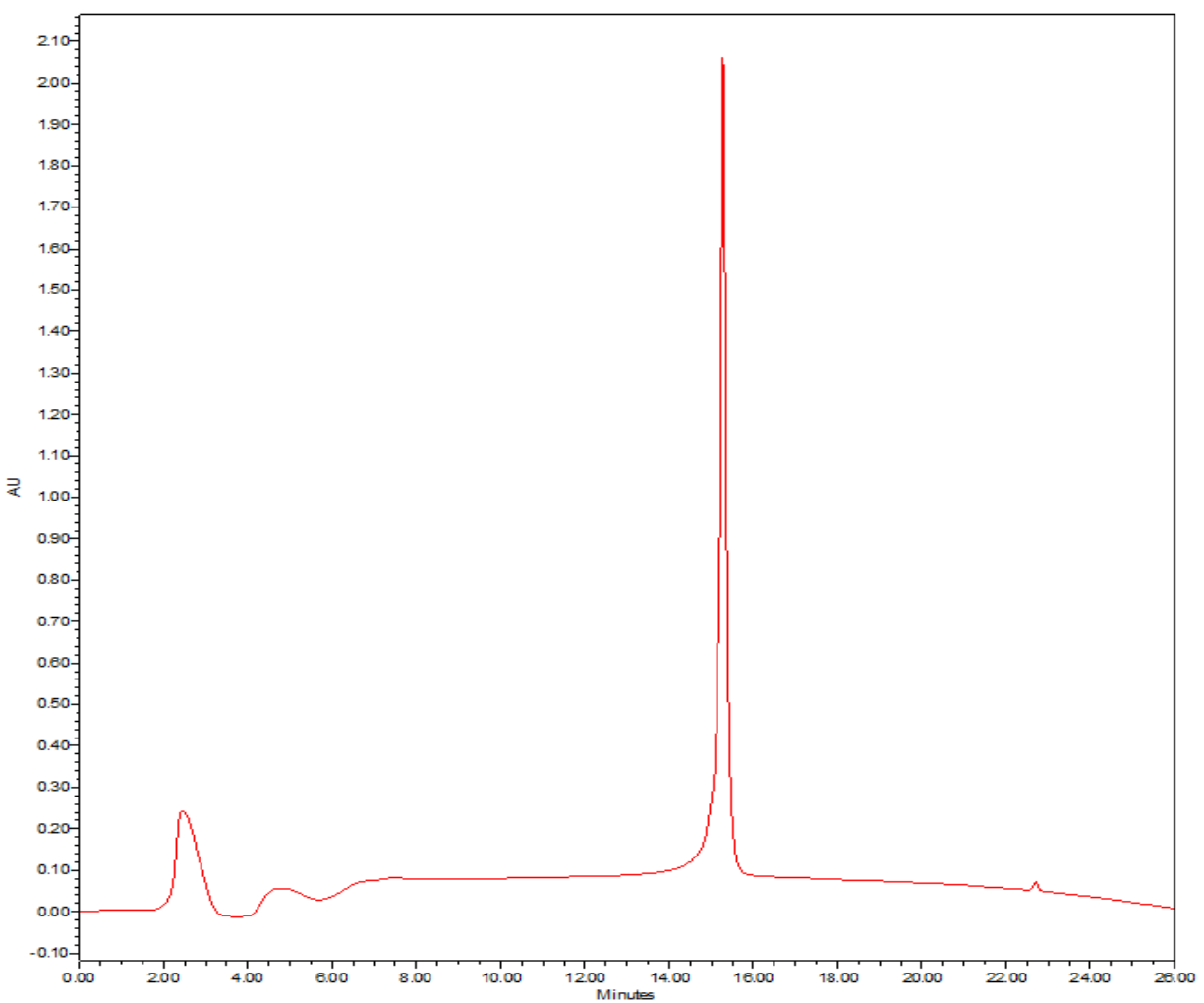

Figure S6. Purity analysis of isolated AE105-PEG8-N3 via analytic HPLC. 


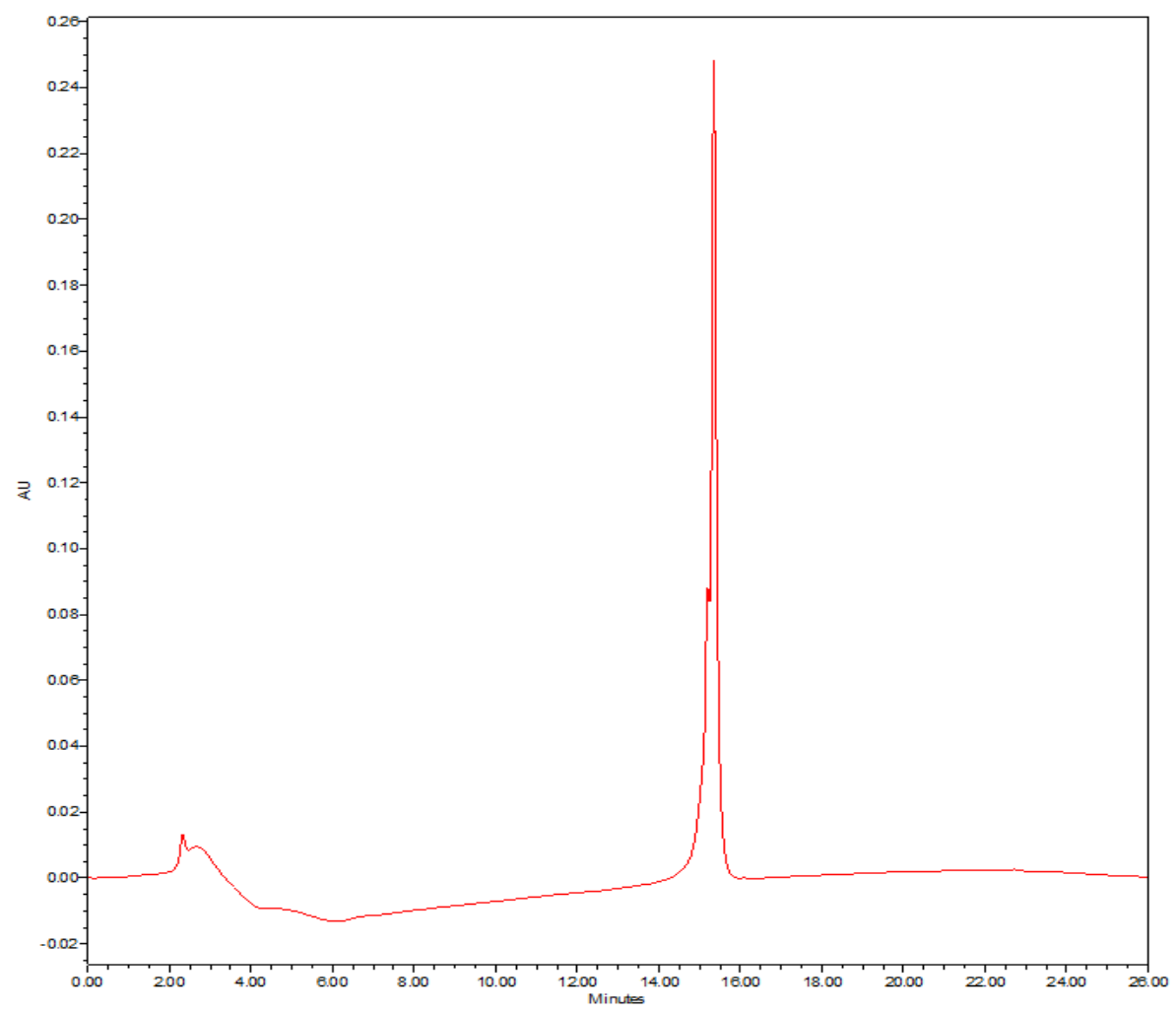

Figure S7. Purity analysis of isolated AE105-PEG12-N3 via analytic HPLC.

8. Absorption spectrum of RGD-PEG4-photo-ODIBO and the activated product RGD-PEG4-ODIBO

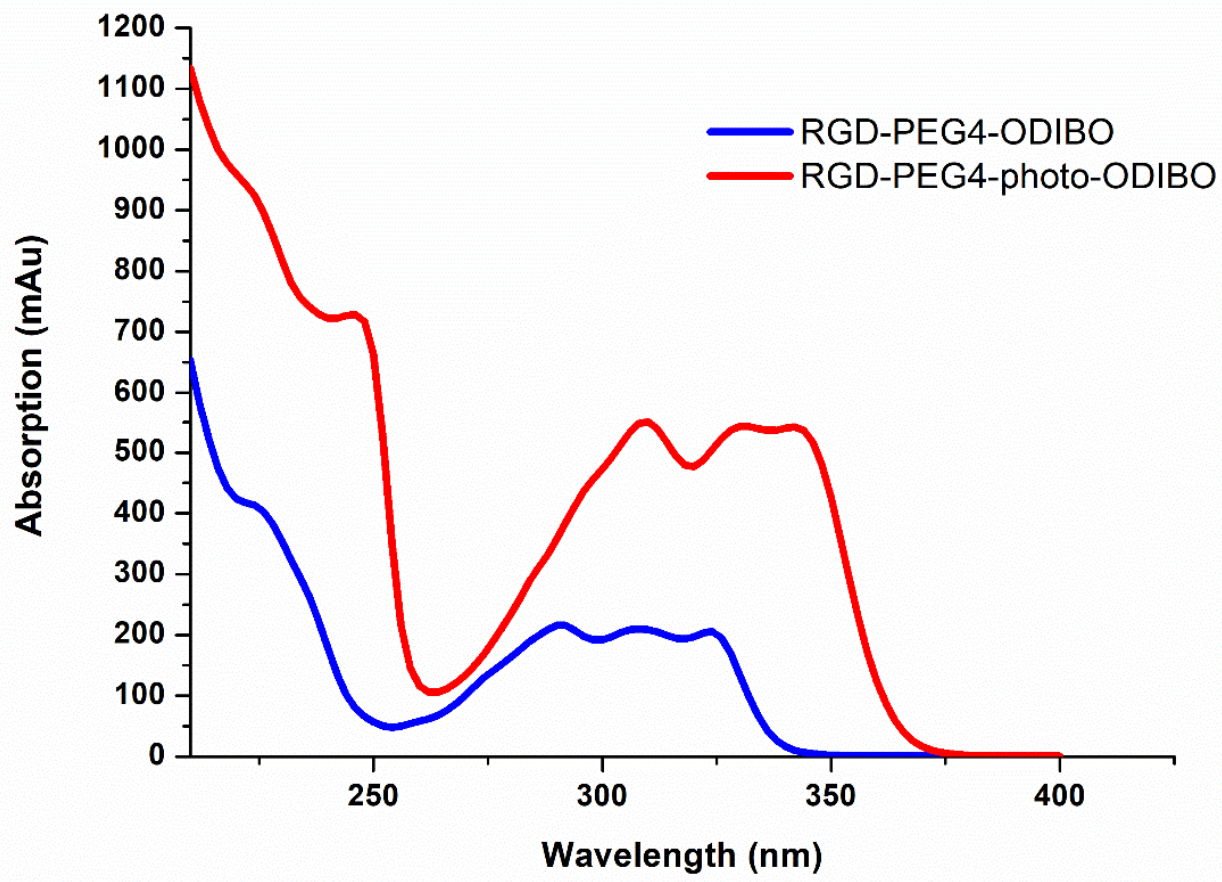

Figure S8. Absorption spectrum of RGD-PEG4-photo-ODIBO and the activated product RGD-PEG4-ODIBO. 


\section{Preparation of heterodimers with different linkers}

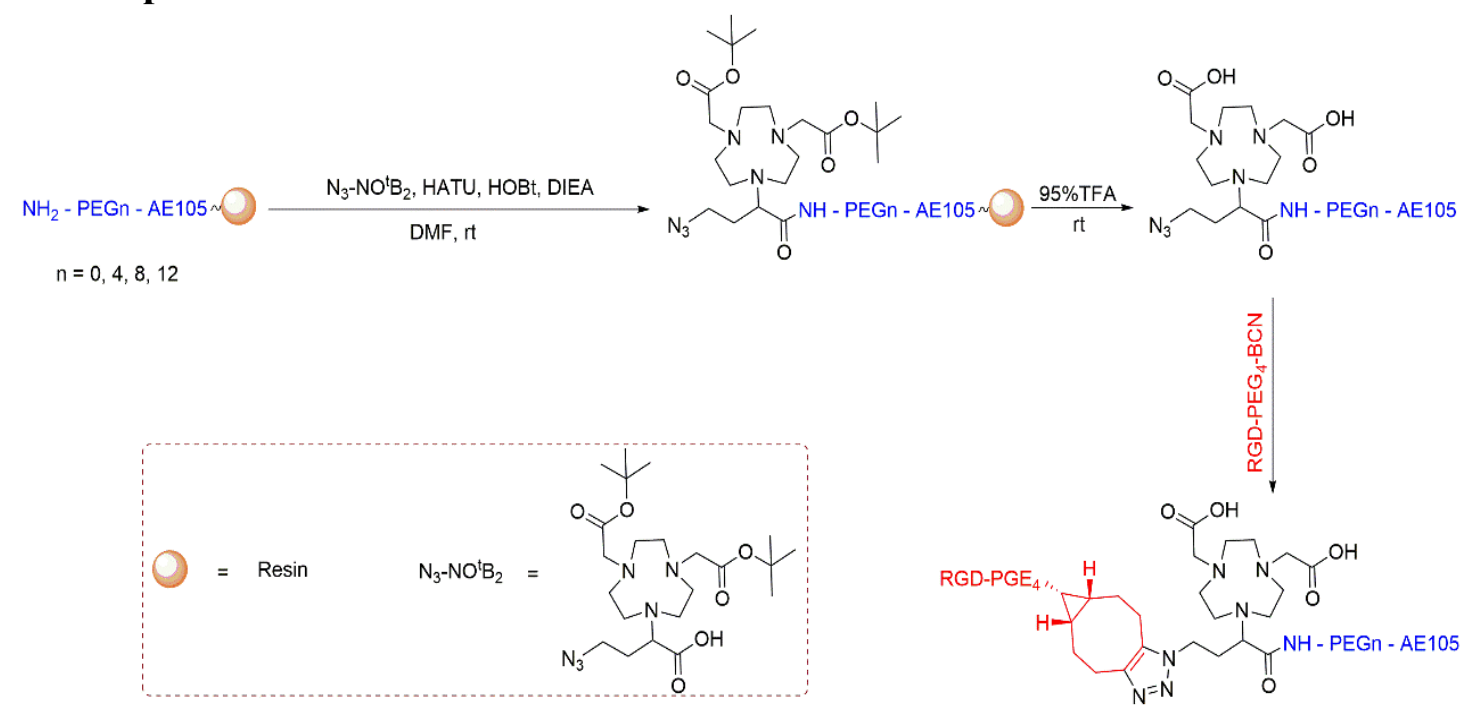

Scheme S3. Preparation of heterodimers with different linkers using our developed BFC.

\section{Statistical analysis}

The results are expressed as mean $\pm \mathrm{SD}$. One-way ANOVA analysis was used to analyze multiple groups. In all statistical analyses, $p<0.05$ was considered statistically significant, and $*, * *, * * *$ indicate $\mathrm{P}<0.05,0.01$ and 0.001 respectively. 